\title{
Perceptions of an Anticipated Bilingual Education Program in Turkey
}

\author{
Burhan Ozfidan ${ }^{1}$, Lynn Burlbaw ${ }^{1} \&$ Li-Jen Kuo ${ }^{1}$ \\ ${ }^{1}$ Texas A\&M University, USA \\ Correspondence: Burhan Ozfidan, Texas A\&M University, USA. E-mail: burhan4977@hotmail.com
}

Received: March 24, 2016

Accepted: April 15, $2016 \quad$ Online Published: September 28, 2016

doi:10.5539/ies.v9n10p174

URL: http://dx.doi.org/10.5539/ies.v9n10p174

\begin{abstract}
Bilingual education is globally an important aspect within the educational community in recent years. The purpose of the study is to explore perceptions towards a bilingual education program and investigate factors that may affect the development of a bilingual education program in Turkey. This study also identifies the benefits of bilingualism in Turkey. The study employed an explanatory sequential mixed method design, which consisted of a quantitative phase followed by a qualitative phase. Data were collected from 40 participants who were graduate students, faculty members, and K-12 teachers. Descriptive analysis was used in the first phase of data analysis; thematic analysis was used in the second phase. A bilingual education program in Turkey might solve the conflict between different ethnic groups. Findings from both phases of data analysis indicated that people in the research group have affirmative perspectives towards a bilingual education program in Turkey.
\end{abstract}

Keywords: bilingual education, Turkish, perceptions, ethnic groups

\section{Introduction}

Developing second language may be comparatively hindered if the mother tongue is not developed well enough (Baker, 2011). Likewise, ignoring the linguistic national resources, which causes children to deny developing their mother tongues, is obviously not reasonable for national self-interest (Skutnabb-Kangas, 2000). Education in mother tongue is an important concern for minority children in several aspects. For instance, individuals who have multilingual or bilingual schooling background and live in diverse cultures develop differently from other individuals whose schooling background based solely on a nation-state understanding. They show more tendencies to use their own mother tongue and their academic achievement is better than others (Baker, 2006; Aydin \& Ozfidan, 2014). However, despite having numerous sub-cultures and being culturally shaped lie a mosaic, Turkey has been ruled under a nation-state mindset for years and did not make a significant progress in the way of education within a multicultural perspective.

There are many ethnic groups in Turkey including, but not limited to Kurds, Arabs, and Laz. These ethnic groups are different from the Turks, and mostly lived in the eastern provinces of the Ottoman Empire with a de facto autonomy (Kiriş̧̧i \& Winrow, 1997). Turkey's largest ethnic groups are Arabs and Kurds, and majority of them inhabit in the southeast of Turkey. Spanning at various times from what is today Algeria to the Caspian Sea, and from Yemen to Hungary and even into Southern Poland, the Ottoman Empire was a mostly unified group of entities that covered a wide variety of languages and cultures (Polat, 2007; Akyol, 2006). The Ottoman Empire did not hinder any ethnic group structure due to the decentralized structure of the empire (Kirişçi \& Winrow, 1997). When the Ottoman Empire had power in this territory, the regions where minority groups inhabited did not have any ethnical and cultural problems, on the contrary, culture and their written literature were developed (Akyol, 2006).

Monolingual mindset of perceiving minority groups as a "threat" and shying them away from different languages is an important question that should be taken into consideration by the Government in Turkey (Coskun, Derince, \& Ucarlar, 2011). Currently, the Government is working on to build a strong bridge to solve the conflict between these ethnic groups bringing their language as an elective into the curriculum in Turkey. This might be a big step for a bilingual education program in Turkey (Ozfidan, 2014; Ozfidan \& Demir, 2014). This study investigates the perception of population towards a possible bilingual education program in Turkey. This study also examines how bilingualism may increase understanding of both languages and cultures, and also builds up brotherhood between Turkish people and other minority groups. 


\section{Literature Review}

Language, both for the group and the individual, is an essential attribute of cultural empowerment and identity and at the same time language is a powerful tool for communication and knowledge (UNESCO, 2003). Therefore, language is important for children's education particularly who are from diverse ethnicities. Many minority children are educated in the majority tongue without developing competence in their mother tongue, which usually causes low academic achievement at school (Cummins, 2001).

\subsection{Bilingual Education}

Bilingual education is a system of education in which instruction is conducted in two languages, typically a mainstream language and a minority language. Bilingual education highlights languages; bilingualism as individual and social phenomena presents program types, variables, diversity, and policies in bilingual education that influence language learning negatively, and concludes by looking at practices, particularly assessments and pedagogies. Bilingual education scholars, including Cummins (2000), Cenoz (2012), Lasagabaster (1998), Genesee and Gandara (1999), have demonstrated that bilingual education adequately provides language skills, which would have substantial positive impact on the society, including aiding in employment, increasing the educational success of students, promoting peace among the members of a society and equality of opportunity for students, contributing to social justice such as equal educational rights, helping to resolve social conflicts among ethnic groups and benefiting students from ethnic minorities.

\subsection{Importance and Beneficiary of Bilingual Education}

Bilingual education has numerous benefits for all children, both native speaking and non-native speaking. Educational psychology research has shown that acquiring a second language in a sociocultural context where both languages are equally valued improves the development of language-cognitive abilities and increases additional intellectual development (Bialystok, Peets, \& Moreno, 2014; Ngai, 2002). Acquiring an additional language also enriches intercultural and interpersonal communication competence, both of which is important for a meaningful and successful life in increasingly various societies and interrelated world (Ngai, 2002; Aydin \& Ozfidan, 2014).

When bilingual education enables people to be successful in both professional and social domains, the main beneficiary of bilingualism is society. Bilingual education perspective increases a nation's inclusive language competence by encouraging the learning of other languages and by increasing and preserving the language resources that minority learners bring to the society (Hakuta, \& National Clearinghouse for Bilingual Education, 1990). This national language competence promotes a worldwide competitiveness, productivity of a country, national security, and effective international diplomacy (Ngai, 2002). A bilingual education program relevant to local languages and cultures would enable to develop a productive society.

Language is vital for the cultural memory's development and the appropriation of the society's history (Ozfidan, Machtmes, \& Demir, 2014). Thus, education in mother tongue is not a threat to unity; on the contrary it brings different ethnic groups together. The quantity and quality of a student's language experience influences his/her ability to learn (UNESCO, 2003). Cummins (2001) argues that ignoring a student's language means that you ignore the student's identity, culture, and customs. Many researchers highlight that forcing minority groups' language to transfer to another language (majority language) can be helpful to their academic success and their learning processes (UNESCO, 2003).

Bilingual education has continuously been a provocative question in educational environment all over the world for a long time (Baker, 2006). One of the controversies is bilingualism allegedly threaten a country's harmony and authority (Cummins, 2000); however, in fact, bilingual education builds a strong bridge among culture and identity in many countries such as many European Countries, South Africa, Spain, the United States, England, and Canada, which accept the diversity of languages (Kaya \& Aydin, 2013). These countries have also designed curriculum programs and models to involve other languages besides accepting new resources and tools when they focus on and reinforce the official language (Ball, 2011). Likewise, according some countries' educational policy (such as Spain and Canada), they teach and adopt a second language along with the official language. Nonetheless, "one language one nation" policy has adapted as a philosophy or dogma in Turkey (Gok, 2010). This situation indicates a problematic equality among students in the field of education since it causes a fundamental human right issue. Mother tongue in education the plays a vital role in incorporating linguistic and cultural productivity.

In a democratic system, national identity is more secure even when it supports the identity of minorities. Bilingual education intends to help students have equal opportunities in education from different ethnicities, 
races, cultural groups, socio-economic statues, and languages (Cummins, 2001; Baker, 2006). In Turkey, when students enter the school they do not have an equal education opportunity because most of the minority students are having a difficulty using the Turkish language. If minority student groups can be integrated into society by adapting their language as a language of education, they may feel more comfortable as a member of the nation because their needs are considered (Polat, 2007; Ozfidan, \& Ugurlu, 2015). According to Aydin (2012), bilingual education will benefit students in Turkey who have distinct background and protect their cultural heritage and mother tongue. In order to improve the language proficiency and academic achievement of minority groups' students, according to a 2013 report by the International Cultural and Research Center (UKAM), it is imperative for the Turkish government to develop special approaches and programs and immediately reform the education system by taking into consideration of their needs.

The following research questions guided the study:

- How are bilingual programs perceived by educators in Turkey?

- How does a bilingual education program benefit the students who come from diverse ethnic background?

\section{Methods}

To address the above research question, an explanatory sequential mixed method study was conducted. The study consisted of two phases: A quantitative phase of study was followed by a qualitative phase (Creswell, 2007; Tashakkori \& Teddlie, 2003). The first phase was a survey instrument that measured educator's perspectives about a possible bilingual education program, specifically on the use of minority groups' language in Turkish education system. The second phase consisted of qualitative data collection through interviewing and analysis to obtain a more comprehensive data set that clarified the necessities of bilingual education program in Turkey. The qualitative portion of the study also consisted of survey questions that attempted to further explore issues identified in the analysis of the quantitative portion of the research project.

\subsection{Participants and Settings}

The participants were a convenience sample of 40 Turkish graduate and undergraduate students who were studying at the University of Nevada, Reno (UNR) in 2013. When the data was collected, the researchers had time management issue to have a survey and interview from the participants due to their workload and course intensiveness at their university. Five of the participants were K-12 teachers who received their master degree in TESOL or ESL and who were working in charter and public schools in Reno, Nevada. Seven of the graduate student participants who participated in this study had studied in ESL. Since most of the participants had linguistics background, the result of the data analysis was more meaningful and thoughtful. Some participants have had the experience of attending other English programs either at other institutions in the US or in other English-speaking countries. Half of the participants were Turks and the other half were from different ethnic groups in Turkey. Participants were recruited through a volunteer sign-up sheet that was handed out asking for volunteers for interviews and surveys. There was no time limitation for the participants to complete the survey.

\subsection{Survey Instrument and Analysis}

The quantitative data for this study was gathered through administering a survey. The survey questions were translated into Turkish and English, and the participants had the opportunity to read the question in the language they primarily spoke. The survey included 4 demographic questions, and 19 Likert Scale questions concerning participants' attitudes and preferences towards bilingual education. These questions were aimed to identify what the participants believed regarding a possible bilingual education program in Turkey. Data was analyzed with descriptive analysis to provide simple summaries about the sample and the measures in the study, and described the basic features of the data.

\subsection{Survey Data Collection and Procedures}

The survey was administered once during the spring semester in 2013. The survey had a separate sign-up sheet where students provided their email addresses if they wished to further contribute to the study by participating in qualitative interviews. The researchers then submitted the survey questionnaire to the participants. Participants were informed that data collected remained confidential.

\subsection{Interview Data Collection and Analysis}

For qualitative data collection, the researchers used semi-structured interviews since the data collection contained open-ended questions (Harrell \& Bradley, 2009). Qualitative data was collected in 10 individual interviews. The first five interviews were with Turkish participants who did not know any ethnic groups' language in Turkey. The second five interviews were with minority people who spoke both Turkish and their 
language fluently. These participants represented a wide variety of experiences within the university as they had dissimilar majors and had studied for various amount of time in the US. The interviews that researchers conducted were completely open about the topic of the current study as well as the participants' role in the research. They were given an option for their responses to be kept confidential.

The researchers met with individuals to receive some suggestions about who would complete the interview. Individuals (pro and anti-bilingualism) were sought out and followed all IRB guidelines set forth by UNR. Once individuals who agreed to participate the study were identified, the researchers met with them in their offices and discussed our purpose of collecting this data. The participants were allowed to know that participation was voluntary and they might abstain at any time during the data collection process and their data would be kept confidential. The participants were also informed that their responses would not be identifiable in the completed report.

The researchers conducted the interviews in the participants' offices and at a location that participants preferred. Using an open-ended interview design, we gathered the qualitative data. This approach allowed us to have open and sincere discussions with the participants and provided them with a more comfortable atmosphere (Willis, 2007). Using an open-ended strategy in this research offered the interviewees the chance to provide thoughtful and enlightening responses. During the interview, this approach also provided more flexibility since the questions built on each other, was conversational, and designed to obtain particular information. The direct interaction and naturalistic environment and face-to-face self-examination allowed the participants to feel sufficiently relaxed to clearly share with their experiences, perceptions and aspects, as they related to content of this study. Researchers afforded the participants an opportunity to read a transcript of their interview and provide us with any further clarification before publication. Participants reflected on old and derive new interpretations of their present and past perceptions of bilingual education.

Thematic analysis was used to identify, organize and report themes that emerged from the data. Themes emerged and named from patterns that the researchers coded on the interview transcript. Theme development was directed by the content of the data (Willis, 2007).

\subsection{Reliability of the Data}

The survey instrument was piloted with a small group of Turkish K-12 public and charter school principals who had been living in the US for about ten years, before the actual administration and then revised for clarity. Furthermore, the survey was reviewed for content/face reliability by two Turkish assistant professors and one Turkish full professor in the field of education in the US. Thus, this survey was found to have excellent content validity.

The Split-Half Procedure was computed to evaluate reliability, such that reliability correlated the even-numbered items with the odd-numbered items. The instrument computed a .67 correlation value for a Split-Half reliability. The Spearman Brown formula was implemented to the Split-Half coefficient to measure reliability. A reliability coefficient of .78 was holistically computed. According to Gravetter and Wallnau (2000), the instrument was considered reliable when the reliability coefficient was .70 or above. Therefore, for this study, the instrument was found to be reliable.

\section{Findings}

\subsection{Survey Data Analysis}

Of 30 surveys that were handed out, all of them were returned completed. Participants represents residents from different regions of Turkey: 6 from Marmara Region, 2 from Aegean Region, 2 from Mediterranean Region, 4 from Central Anatolia Region, 2 from Black Sea Region, 4 from Southeastern Anatolia Region, and the highest percentage, 8 from Eastern Anatolia Region. Half of the participants were Turks and the other half were from different ethnic groups in Turkey. In the study, 20 of the participants were graduate and undergraduate students at University of Nevada, Reno (UNR); 2 of the participants were professors; and 6 of the participants were K-12 teachers in charter and public schools and the rest did not indicate their current positions. Half of the participants spoke both Turkish and their ethnic language, and the other half spoke only Turkish. 
Table 1. Items and percentage of participants

\begin{tabular}{|c|c|c|c|c|c|c|}
\hline \multicolumn{7}{|c|}{ I believe bilingual education IN TURKEY would: } \\
\hline Answer Options & $\begin{array}{l}\text { Strongly } \\
\text { Disagree }\end{array}$ & Disagree & Neutral & Agree & $\begin{array}{l}\text { Strongly } \\
\text { Agree }\end{array}$ & $\mathrm{N}$ \\
\hline $\begin{array}{l}\text { 1. Preserve minority groups' } \\
\text { linguistic and cultural heritage. }\end{array}$ & $\begin{array}{l}0.0 \% \\
(0)\end{array}$ & $13.3 \%(4)$ & $0.0 \%(0)$ & $\begin{array}{l}33.3 \% \\
(10)\end{array}$ & $\begin{array}{l}53.3 \% \\
(16)\end{array}$ & 30 \\
\hline $\begin{array}{l}\text { 2. Assist immigrant acculturation } \\
\text { to a new society. }\end{array}$ & $\begin{array}{l}6.7 \% \\
(2)\end{array}$ & $\begin{array}{l}6.7 \% \\
(2)\end{array}$ & $6.7 \%(2)$ & $\begin{array}{l}66.7 \% \\
(20)\end{array}$ & $13.3 \%(4)$ & 30 \\
\hline $\begin{array}{l}\text { 3. Help assimilate individuals or } \\
\text { groups into mainstream society and } \\
\text { socialize people for full } \\
\text { participation in the community. }\end{array}$ & $\begin{array}{l}7.6 \% \\
(2)\end{array}$ & $\begin{array}{l}7.1 \% \\
(2)\end{array}$ & $\begin{array}{l}21.4 \% \\
(6)\end{array}$ & $\begin{array}{l}28.6 \% \\
(8)\end{array}$ & $\begin{array}{l}35.3 \% \\
(10)\end{array}$ & 28 \\
\hline $\begin{array}{l}\text { 4. Preserve ethnic and religious } \\
\text { identity. }\end{array}$ & $\begin{array}{l}6.7 \% \\
(2)\end{array}$ & $\begin{array}{l}0.0 \% \\
(0)\end{array}$ & $\begin{array}{l}13.3 \% \\
(4)\end{array}$ & $\begin{array}{l}40.0 \% \\
(12)\end{array}$ & $\begin{array}{l}40.0 \% \\
(12)\end{array}$ & 30 \\
\hline $\begin{array}{l}\text { 5. Increase understanding of both } \\
\text { languages and cultures. }\end{array}$ & $\begin{array}{l}6.7 \% \\
(2)\end{array}$ & $\begin{array}{l}0.0 \% \\
(0)\end{array}$ & $0.0 \%(0)$ & $\begin{array}{l}20.0 \% \\
(6)\end{array}$ & $\begin{array}{l}73.3 \% \\
(22)\end{array}$ & 30 \\
\hline Mean Percentage (\%) & 5.54 & 5.42 & 8.28 & 37.72 & 43.04 & \\
\hline answered question & & & & & & 30 \\
\hline skipped question & & & & & & 2 \\
\hline
\end{tabular}

In Table 1, items 1 through 5 consist of phrases aimed at identifying whether participants agree, disagree, strongly agree, strongly disagree, or are neutral. According to the Table 1, 38 \% of the participants agreed with all the statements and $43 \%$ of the participants strongly agreed with all the statements, which indicates that participants have higher positive perception towards bilingual education. Results in Table 1 indicate the participants' belief that a bilingual education program in Turkey preserves minority groups' linguistic and cultural heritage, ethnic and religious identity, and assist immigrant acculturation to a new society. Table 1 also shows that an anticipated bilingual education program prevent from assimilating individuals or groups into mainstream society and socialize people for full participation in the community. Additionally, the results indicate that bilingual education increases understanding of both languages and cultures, and also increase brotherhood between Turkish and minority people; in other words, it does not cause any ethnical segregation between Turkish and other minority groups in Turkey.

Table 2. Mean scores and standard deviation values in bilingual education perception scale (Strongly Disagree: 1, Disagree: 2, Neutral: 3, Agree: 4, Strongly Agree: 5)

\begin{tabular}{|c|c|c|c|c|}
\hline \multicolumn{2}{|c|}{ Items } & Mean & SD & $\mathrm{N}$ \\
\hline 1) & $\begin{array}{l}\text { Preserve minority groups' linguistic and cultural } \\
\text { heritage. }\end{array}$ & 4.27 & 1.02 & 30 \\
\hline 2) & Assist immigrant acculturation to a new society. & 3.73 & 1.01 & 30 \\
\hline 3) & $\begin{array}{l}\text { Help assimilate individuals or groups into } \\
\text { mainstream society and socialize people for full } \\
\text { participation in the community. }\end{array}$ & 3.78 & 1.23 & 28 \\
\hline 4) & Preserve ethnic and religious identity. & 4.07 & 1.08 & 30 \\
\hline 5) & $\begin{array}{l}\text { Increase understanding of both languages and } \\
\text { cultures. }\end{array}$ & 4.53 & 1.04 & 30 \\
\hline
\end{tabular}

In Table 2, the highest mean score is 4.53 , which will indicate that bilingual education in Turkey increase the understanding of both languages and cultures. The lowest mean score is 3.73 , which shows that bilingual 
education in Turkey will assist immigrant acculturation to a new society. Table 2 also indicates that the $3^{\text {rd }}$ item has the highest standard deviation value with 1.23 , which shows that in item 3 , there is a high level of differentiation and the $2^{\text {nd }}$ item has the lowest standard deviation value with 1.01 , which indicates that in item 2 , there is a low level of differentiation. A high standard deviation indicates a heterogeneous group.

Table 3. Percentage of participants' opinion on bilingual education

\begin{tabular}{|c|c|c|c|c|c|c|}
\hline Items & $\begin{array}{l}\text { Strongly } \\
\text { Disagree }\end{array}$ & Disagree & Neutral & Agree & $\begin{array}{c}\text { Strongly } \\
\text { Agree }\end{array}$ & $\mathrm{N}$ \\
\hline $\begin{array}{l}\text { 1. Currently, children who come from } \\
\text { minority group background and start } \\
\text { school with poor Turkish language } \\
\text { skills often do not continue their } \\
\text { education. }\end{array}$ & $\begin{array}{c}0.0 \% \\
(0)\end{array}$ & $14.6 \%(4)$ & $\begin{array}{c}0.0 \% \\
(0)\end{array}$ & $\begin{array}{c}64.3 \% \\
(18)\end{array}$ & $21.1 \%(6)$ & 28 \\
\hline $\begin{array}{l}\text { 2. Bilingual education provides } \\
\text { language skills, which are marketable, } \\
\text { aiding in employment and status. }\end{array}$ & $\begin{array}{l}7.1 \% \\
(2)\end{array}$ & $\begin{array}{l}0.0 \% \\
(0)\end{array}$ & $14.3 \%(4)$ & $\begin{array}{c}35.7 \% \\
(10)\end{array}$ & $42.9 \%(12)$ & 28 \\
\hline $\begin{array}{l}\text { 3. Integrating minority groups' } \\
\text { languages in schools would help } \\
\text { children who come from ethnic } \\
\text { minority background be successful. }\end{array}$ & $\begin{array}{c}7.1 \% \\
(2)\end{array}$ & $\begin{array}{c}0.0 \% \\
(0)\end{array}$ & $\begin{array}{c}0.0 \% \\
(0)\end{array}$ & $\begin{array}{c}57.1 \% \\
(16)\end{array}$ & $35.7 \%(10)$ & 28 \\
\hline $\begin{array}{l}\text { 4. A bilingual educational program } \\
\text { would be good for both minority ethnic } \\
\text { background and Turkish children. }\end{array}$ & $\begin{array}{c}0.0 \% \\
(0)\end{array}$ & $\begin{array}{l}7.1 \% \\
(2)\end{array}$ & $14.3 \%(4)$ & $\begin{array}{c}50.0 \% \\
(14)\end{array}$ & $28.6 \%(8)$ & 28 \\
\hline $\begin{array}{l}\text { 5. I am supportive of bilingual } \\
\text { education in Turkey. }\end{array}$ & $\begin{array}{l}7.7 \% \\
(2)\end{array}$ & $\begin{array}{l}0.0 \% \\
(0)\end{array}$ & $\begin{array}{l}0.0 \% \\
(0)\end{array}$ & $\begin{array}{c}38.5 \% \\
(10)\end{array}$ & $53.8 \%(14)$ & 26 \\
\hline $\begin{array}{l}\text { 6. Bilingual education programs should } \\
\text { focus on the formal rules of spelling } \\
\text { and grammar. }\end{array}$ & $\begin{array}{l}7.1 \% \\
(2)\end{array}$ & $14.3 \%(4)$ & $28.6 \%(8)$ & $\begin{array}{c}42.9 \% \\
(12)\end{array}$ & $\begin{array}{c}7.1 \% \\
(2)\end{array}$ & 28 \\
\hline $\begin{array}{l}\text { 7. Bilingual education programs should } \\
\text { focus on communication, speaking, and } \\
\text { listening. }\end{array}$ & $\begin{array}{c}0.0 \% \\
(0)\end{array}$ & $14.3 \%(4)$ & $\begin{array}{l}7.1 \% \\
(2)\end{array}$ & $\begin{array}{c}35.7 \% \\
(10)\end{array}$ & $42.9 \%(12)$ & 28 \\
\hline $\begin{array}{l}\text { 8. Bilingual education should look at } \\
\text { the Turkish alphabet and its history. }\end{array}$ & $\begin{array}{c}0.0 \% \\
(0)\end{array}$ & $\begin{array}{l}7.1 \% \\
(2)\end{array}$ & $15.3 \%(4)$ & $\begin{array}{c}69.2 \% \\
(18)\end{array}$ & $\begin{array}{l}7.1 \% \\
(2)\end{array}$ & 26 \\
\hline $\begin{array}{l}\text { 9. Minority groups' language sessions } \\
\text { should focus on the development of } \\
\text { vocabulary and practical speaking. }\end{array}$ & $\begin{array}{l}0.0 \% \\
(0)\end{array}$ & $\begin{array}{l}7.1 \% \\
(2)\end{array}$ & $\begin{array}{l}7.1 \% \\
(2)\end{array}$ & $\begin{array}{c}53.8 \% \\
(14)\end{array}$ & $28.6 \%(8)$ & 26 \\
\hline $\begin{array}{l}\text { 10. I am concerned that children who } \\
\text { come from ethnic background might } \\
\text { lose fluency in their mother tongue and } \\
\text { face communication problems with } \\
\text { their parents. }\end{array}$ & $\begin{array}{c}0.0 \% \\
(0)\end{array}$ & $\begin{array}{c}7.3 \% \\
(2)\end{array}$ & $14.3 \%(4)$ & $\begin{array}{c}35.6 \% \\
(10)\end{array}$ & $42.9 \%(12)$ & 28 \\
\hline $\begin{array}{l}\text { 11. The minority groups' language } \\
\text { should be offered as an elective course } \\
\text { in primary schools. }\end{array}$ & $\begin{array}{l}0.0 \% \\
(0)\end{array}$ & $\begin{array}{l}7.1 \% \\
(2)\end{array}$ & $\begin{array}{l}7.1 \% \\
(2)\end{array}$ & $\begin{array}{c}35.7 \% \\
(10)\end{array}$ & $50.0 \%(14)$ & 28 \\
\hline Mean Percentage (\%) & 2.64 & 7.17 & 9.82 & 47.14 & 32.79 & \\
\hline \multicolumn{6}{|c|}{ answered question } & 26 \\
\hline \multicolumn{6}{|c|}{ skipped question } & 4 \\
\hline
\end{tabular}


Table 3 provides an overall summary of the descriptive findings for this part. For Table 3, items 1 through 11 consist of phrases aimed at identifying if participants agree, disagree, strongly agree, strongly disagree, or are neutral. Table 3 indicates that minority groups' children who start school with poor Turkish language skills often do not continue their education. Hence, they are having a difficulty finding a job or a position in any company. Results also indicate that bilingual education provides language skills, which are essential, aiding in employment and status. Therefore, according to results, integrating minority language in schools helps minority groups' children be successful. Table 3 also indicates that $92.3 \%$ of the participants are supportive of bilingual education in Turkey. As a structure of an anticipated bilingual education program in Turkey, Table 3 indicates that bilingual education program should focus on the formal rules of spelling and grammar, communication, speaking, and listening; however, that should be decided by bilingual curriculum instructors in the future.

Table 4. Mean scores and standard deviation values in bilingual education perception scale (Strongly Disagree: 1, Disagree: 2, Neutral: 3, Agree: 4, Strongly Agree: 5)

\begin{tabular}{|c|c|c|c|c|}
\hline \multicolumn{2}{|c|}{ Items } & \multirow{2}{*}{$\begin{array}{l}\text { Mean } \\
3.93\end{array}$} & \multirow{2}{*}{$\begin{array}{l}\text { SD } \\
0.90\end{array}$} & \multirow{2}{*}{$\frac{\mathrm{N}}{28}$} \\
\hline 1) & $\begin{array}{l}\text { Currently, children who come from minority group background and start school with } \\
\text { poor Turkish language skills often do not continue their education. }\end{array}$ & & & \\
\hline 2) & $\begin{array}{l}\text { Bilingual education provides language skills, which are marketable, aiding in } \\
\text { employment and status. }\end{array}$ & 4.07 & 1.12 & 28 \\
\hline 3) & $\begin{array}{l}\text { Integrating minority groups' languages in schools would help children who come from } \\
\text { ethnic minority background be successful. }\end{array}$ & 4.14 & 1.01 & 28 \\
\hline 4) & $\begin{array}{l}\text { A bilingual educational program would be good for both minority ethnic background } \\
\text { and Turkish children. }\end{array}$ & 4 & 0.86 & 28 \\
\hline 5) & I am supportive of bilingual education in Turkey. & 4.31 & 1.09 & 26 \\
\hline 6) & $\begin{array}{l}\text { Bilingual education programs should focus on the formal rules of spelling and } \\
\text { grammar. }\end{array}$ & 3.28 & 1.05 & 28 \\
\hline 7) & Bilingual education programs should focus on communication, speaking, and listening. & 4.07 & 1.05 & 28 \\
\hline 8) & Bilingual education should look at the Turkish alphabet and its history. & 3.77 & 0.71 & 26 \\
\hline 9) & $\begin{array}{l}\text { Minority groups' language sessions should focus on the development of vocabulary } \\
\text { and practical speaking. }\end{array}$ & 4.08 & 0.84 & 26 \\
\hline 10) & $\begin{array}{l}\text { I am concerned that children who come from ethnic background might lose fluency in } \\
\text { their mother tongue and face communication problems with their parents. }\end{array}$ & 4.14 & 0.93 & 28 \\
\hline 11) & $\begin{array}{l}\text { The minority groups' language should be offered as an elective course in primary } \\
\text { schools. }\end{array}$ & 4.28 & 0.90 & 28 \\
\hline
\end{tabular}

Table 4 indicates that the highest mean score is 4.31 , which indicates that participants are very supportive towards a possible bilingual education program in Turkey and the lowest mean score is 3.28, which shows that bilingual education in Turkey structurally should focus on formal rules of spelling and grammar. Table 4 also indicates that the 2 nd item has the highest standard deviation value with 1.12 , which shows that in item 2, there is a high level of differentiation and the $8^{\text {th }}$ item has the lowest standard deviation value with .71 , which indicates that in item 8 , there is a low level of differentiation. A high standard deviation indicates a heterogeneous group.

All in all, according to the results of the survey, the majority of participants, both Turkish and other minority groups, believe that a bilingual educational program would be beneficial for both Turkish and minority groups' children. The survey showed that $92 \%$ of the participants are supportive of bilingual education in Turkey. As a curriculum, the participants stated that a possible bilingual education program should focus on the formal rules of spelling, grammar, communication, speaking, listening, and the development of vocabulary.

\subsection{Interview Data Analysis}

The first interview population was five Turkish participants who did not know the minority groups' languages (Group A). The second interview population was five participants who come from minority group and spoke at least two languages fluently (Group B). Both groups' participants were teachers in high schools in the United States. From these interviews, the interviewees' perspectives on anticipated bilingualism in Turkey were 
gathered and analyzed. Emergent themes in the interviews were coded.

\subsubsection{Theme One: Acceptance of Minority Groups' Language}

The first theme apparent from the interview was the participants' acceptance of minority groups' language. According to the Group A's participants, from the beginning of their school life, minority groups' children encounter the "feeling of being a loser"; therefore, these children cope with feelings of being behind because they try to learn a language rather developing their academic subjects. The participants discussed those questions and provided bilingual education examples from other countries such as Basque bilingual education models. They also pointed out that developing a model for Turkish education system might not be easy but it is not difficult either. Group B highlighted that when they started primary school, they obviously realized that speaking their language during breaks let alone in class was not allowed. According to this group, they learned "be quiet" as a first Turkish word while they were in primary school. They also felt alienated and were uncomfortable going to school. They also stated that in their childhood they feared losing fluency in their native language and encountering communication difficulties with their parents when they improved their Turkish.

\subsubsection{Theme Two: Language Issues}

The second theme in the interview was a solution to these language issues in Turkey. Group A acknowledged a bilingual educational curriculum should be created and include: developing some departments at universities (particularly in Eastern part of Turkey because most of the minority people live in this territory) to train and prepare teachers for a bilingual education program; allowing teachers who can speak minority groups' language to specialize in bilingual a specific education method; training teachers on diversities of the cultures and languages; transforming the dominant teacher/submissive student relations; opening minority groups' literacy courses for the parents; and encouraging bilingual TV programs for students.

According to Group B, minority groups' parents who cannot speak Turkish said they were not able to help their children and they had a difficultly to attend the school meetings since they have a poor Turkish language, but they were encouraging their kids to acquire Turkish language. Overall, the respondents in Group B emphasized

most of the minority groups' students feel they are not very smart because of their language difficulties and that causes lack of motivation, not studying hard enough, and feeling more stressed. Students want to be educated but since their Turkish is not sufficiently good they don't want to go to school and they miss the opportunity to continue their education.

According to Group B, some people do not necessarily disagree with the right to education in one's mother language. As a matter of fact, in most cases they support the principle behind the revitalization of minority languages as a means to preserve and promote minority cultures. Interviews with this group also suggested that the majority of people argue for the necessity of having an official language. Overall, the respondents in Group B emphasized

the need for all those who are citizens of Turkey to learn the Turkish language in order to be able to communicate with the rest of the society. Therefore, the practical aspect of communication emerged as the primary issue that needs to be addressed in debates on bilingual education.

\subsubsection{Theme Three: Cultural Right}

A third theme that emerged was the participants' feeling that cultural rights are important to bilingual education. A member of Group B stated, "freedom of expression is not applied in the same manner to the minority language as it is to the Turkish language. Besides, the Governmental policy in Turkey indicates some of the minority groups as a terrorist group." According to this participant, such discrimination is also found in the minority groups' geographic areas. Commemorating holidays and celebrations were controlled and limited by the authorities in the past; however, currently it is more flexible. Moreover, in the past, the refusal of government to support such cultural problems resulted in violence and arbitral detention of minority people. Another member of Group B stated, "If one's mother language staged out, in other words, one's cultural heritages will be vanished...if one doesn't have a chance to practice his/her mother tongue it may get rusty." The new generation could not inherit cultural and historical achievements without the language. The responses in Group B, reflected the belief that protecting cultural heritage and one's own language is a fundamental human rights reinforced by today's worldwide society, consistent with the United Nation position (UNESCO, 1974). Participants stated that minority groups 'language might disappear, if bilingualism does not appear in Turkey, as its functions as a communication tool declines with globalization and modernization. They also felt that a language's disappearance is foreseeable, although community can't sensitively recognize the disappearance. If a minority group rejects learning other useful languages, but insists on protecting its own language, the group's limited 
capacity to communicate and learn will place them at a disadvantage in international and social competition, and hinder their opportunities in future development (May, 2001).

\subsubsection{Theme Four: Structure of Minority Language}

The fourth emergent theme apparent from the interview is that the participants addressed importance of teaching the structure of the minority language. Group A stated that the structure of the minority language should aim to address their alphabet and its primary structure in bilingual curricula. The target language, according to Group A, should be their language (Turkish word for their language) and according the Group B, a course for bilingual curricula should require students to express themselves in their mother tongue with the basic knowledge by exhibiting "the fundamental vocabulary and structure of grammatical rules" used in daily life. They also stated that developing students' knowledge of vocabulary and grammar might encourage the students to improve writing ability in their mother tongue. The curricula should offer this course for students who cannot speak their mother tongue very well.

Overall, both Group A and B mentioned the positive effect of minority groups' language integration on the Turkish national state. The actual situation of the minority groups' language has considerably changed in the last two decades. In order for the linguistic rights to be applied fully, for the linguistic rights to be granted in education, justice, politics, etc., and for the minority groups' language to be officially recognized, much future work such as having a bilingual model should be done. There is also confusion between what is done and what is allowed. It is crucial that this issue is addressed, official recognition is given, and rights are granted. Considering at least in daily language practice, the huge changes that caused the minority groups' issues will certainly continue to move towards more freedom, more rights and more recognition. This can only be beneficial for Turkey, the minority groups' language, and the minority groups' people.

\section{Conclusion and Discussion}

This research particularly focuses on perceptions of bilingual education in Turkey. Education must effectively address the instructional needs of individuals from linguistic and cultural diversities based on global changes all over the world (Ilhan \& Aydin, 2015). In our study, we showed with both survey and interview that most of the participants are supportive of bilingual education in Turkey. The survey results indicate that $92 \%$ of participants have a high positive attitude towards bilingual education. Bilingual education benefits students to be more successful in academia (Baker, 2011; Cummins, 2001; Gok, 2010). According to the findings, bilingual education in Turkey will help students to be more successful. Findings also indicate that bilingual education can provide job opportunities for students' future career.

Bilingual education helps to protect identity, cultural heritage, and linguistic rights (May, 2001; Ngai, 2002; Skutnabb-Kangas, 2000) and it does not cause segregation among the ethnic groups (Hakuta \& National Clearinghouse for Bilingual Education, 1990). Findings indicate that a bilingual education program in Turkey could conserve minority groups' linguistic rights, cultural heritage, and identity. Additionally, findings also show that a bilingual education program in Turkey will increase brotherhood between Turks and the minority groups, and also increase understanding of both languages and cultures; in other words, it does not cause any ethnical segregation between Turkish and people who come from diverse ethnic background.

\section{References}

Akyol, M. (2006). The Origin of Turkey's Kurdish Question: An Outcome of the Breakdown of the Ottoman Ancien Régime (Master thesis, Bogazici University).

Aydin, H. (2012). Multicultural Curriculum Development in Turkey. Mediterranean Journal of Social Sciences, $3(3), 277-286$.

Aydin, H., \& Ozfidan, B. (2014). Perceptions on Mother Tongue (Kurdish) Based Multicultural and Bilingual Education in Turkey. Multicultural Education Review (MER), 6(1), 51-78

Baker, C. (2006). Foundations of Bilingual Education and Bilingualism. Clevedon; Buffalo: Multilingual Matters.

Baker, C. (2011). Foundations of Bilingual Education and Bilingualism. Bristol, UK; Tonawanda, N.Y.: Multilingual Matters.

Ball, J. (2011). Enhancing Learning of Children from Diverse Language Backgrounds. France: UNESCO.

Bialystok, E., Peets, K. F., \& Moreno, S. (2014). Producing Bilinguals through Immersion Education: Development of Metalinguistic Awareness. Applied Psycholinguistics, 35(1), 177-191. http://dx.doi.org/10.1017/S0142716412000288 
Cenoz, J. (2012). Bilingual Educational Policy in Higher Education in the Basque Country. Language, Culture And Curriculum, 25(1), 41-55. http://dx.doi.org/10.1080/07908318.2011.653057

Coskun, V., Derince, M. S., \& Ucarlar, N. (2011). Scar of Tongue: Consequences of the Ban on the Use of Mother Tongue in Education and Experiences of Kurdish Students in Turkey. Diyarbakir Institute for Political and Social Research.

Creswell, J. W. (2007). Qualitative Inquiry and Research Design: Choosing Among Five Approaches (2nd ed.). Thousand Oaks, CA: Sage.

Cummins, J. (1991). Language Development and Academic Learning. In L. Malave, \& G. Duquette (Eds.), Language, culture and cognition. Clevedon: Multilingual Matters.

Cummins, J. (2000). Language, Power, and Pedagogy. Bilingual Children in the Crossfire. Clevedon, England: Multilingual Matters.

Cummins, J. (2001). Bilingual Children's Mother Tongue: Why is it important for education. Sprogforum, 19, $15-20$.

Genesee, F., \& Gándara, P. (1999). Bilingual education programs: A cross-national perspective. Journal of Social Issues, 55(4), 665-685. http://dx.doi.org/10.1111/0022-4537.00141

Gok, F. (2010). Mother Tongue Based Education in the Context of Educational Rights. The Importance of Mother Tongue and Education, 73-83. Ankara: Egitim Sen.

Gravetter, F., \& Wallnau, L. (2000). Statistics for the Behavioral Sciences. Belmont, CA.: Wadsworth/Thomson Learning.

Hakuta, K., \& National Clearinghouse for Bilingual Education. (1990). Bilingualism and Bilingual Education: A Research Perspective. Occasional Papers in Bilingual Education, Number 1.

Harrell, M. C., \& Bradley, M. (2009). Data Collection Methods: Semi-structured Interviews and Focus Groups: Training Manual/Margaret C. Harrell, Melissa A. Bradley. Santa Monica, CA: RAND, c2009.

Ilhan, D., \& Aydin, H. (2015). Perceptions of Higher Education Faculty Members on Bilingual Education in Turkey. Journal Of Education And Training Studies, 3(3), 146-155. http://dx.doi.org/10.11114/jets.v3i3.694

Kaya, I., \& Aydin, H. (2013). Challenges, Experiences, and Model Recommendations for Bilingual Education. Istanbul: UKAM Press.

Kirişçi, K., \& Winrow, G. M. (1997). The Kurdish Question and Turkey: An Example of a Trans-state Ethnic Conflict. Portland, Oregon: Frank Cass Publishers (p. 23).

Lasagabaster, D. (1998). The Threshold Hypothesis Applied to Three Languages in Contact at School. International Journal Of Bilingual Education And Bilingualism, 1(2), 119-33. http://dx.doi.org/10.1080/13670059808667678

May, S. (2001). Language and Minority Rights: Ethnicity, Nationalism, and the Politics of Language. New York: Longman.

Ngai, P. B. (2002). Bilingual Education for All: A Benefits Model for Small Towns. Bilingual Research Journal, 26(2), 269-94. http://dx.doi.org/10.1080/15235882.2002.10668711

Ozfidan, B. (2014). The Basque Bilingual Education System: A Model for a Kurdish Bilingual Education System in Turkey. Journal of Language Teaching \& Research, 5(2), 382-390. http://dx.doi.org/10.4304/j1tr.5.2.382-390

Ozfidan, B., \& Demir, H. (2014). Bask Çift Dilli Egitimi ve Bunun Turkiyedeki Olasi Çift Dilli Egitim İcin Örneklendirilmesi. Asian Journal of Instruction (AJI), 2(1(ÖZEL)), 77-85.

Ozfidan, B., \& Ugurlu, O. (2015). The Idea of Race And Racial Differences. Electronic International Journal of Education, Arts, and Science, 1(1), 85-98.

Ozfidan, B., Machtmes, K., \& Demir, H. (2014). Socio-cultural Factors in Second Language Learning: A Case Study of Adventurous Adult Language Learners. European Journal of Education Research, 3(4), 185-191. http://dx.doi.org/10.12973/eu-jer.3.4.185

Polat, N. (2007). Socio-psychological Factors in the Attainment of L2 Native-like Accent of Kurdish Origin Young People Learning Turkish in Turkey (PhD diss., The University of Texas at Austin).

Skutnabb-Kangas, T. (2000). Linguistic Genocide in Education-or Worldwide Diversity and Human Rights? 
Mahwah, NJ: Lawrence Erlbaum Associates.

Tashakkori, A., \& Teddlie, C. (2003). The Past and Future of Mixed Methods Research: From Data Triangulation to Mixed Model Designs. In A. Tashakkori, \& C. Teddlie (Eds.), Handbook of mixed methods in social and behavioral research (pp. 671-702). Thousand Oaks, CA: Sage.

Ugurlu, O., \& Ozfidan, B. (2015). A Refugee Group's Mental Health and Social Care. Electronic International Journal of Education, Arts, and Science, 1(1), 99-114.

UKAM. (2013). Kürt Sorunu ve Çözüm Süreci Algı Araştırması [Kurdish Issues and the Process of its Solution]. Istanbul, Turkey: Kaya. I., Aydin. H., Gultekin, M.

UNESCO. (1974). Recommendation Concerning Education for International Understanding, Co-operation and Peace and Education Relating to Human Rights and Fundamental Freedoms. Paper presented at the annual meeting for the Society of eighteenth session Paris, July 6-10.

UNESCO. (2003). Education in a Multilingual World. Paris: United Nations Educational, Scientific and Cultural Organization.

Willis, J. W. (2007). Foundations of Qualitative Research: Interpretive and Critical Approaches. Thousand Oaks, CA: Sage. http://dx.doi.org/10.4135/9781452230108

\section{Copyrights}

Copyright for this article is retained by the author(s), with first publication rights granted to the journal.

This is an open-access article distributed under the terms and conditions of the Creative Commons Attribution license (http://creativecommons.org/licenses/by/4.0/). 